\title{
Estimate of Undiscovered Copper Resources of the World, 2013
}

\author{
Using a geology-based assessment methodology, \\ the U.S. Geological Survey estimated a mean of \\ 3,500 million metric tons of undiscovered copper \\ among 225 tracts around the world.
}

\section{Introduction}

Informed planning and decisions concerning future mineral supplies, sustainability, and resource development require a long-term global perspective and an integrated approach to land use and to resource and environmental management. This integrated approach further requires unbiased information on the global distribution of identified and undiscovered mineral resources, the economic factors influencing their development, and the environmental consequences of their exploitation.
The U.S. Geological Survey (USGS), the principal Federal provider of research and information on nonfuel mineral resources, has completed a geology-based, cooperative international assessment of copper resources of the world. Collaborators in this assessment include mineral resource experts from national geological surveys and from industry and academia worldwide.

This assessment indicates that in addition to identified copper resources of 2,100 million metric tons (Mt), a mean of 3,500 Mt of undiscovered copper

Table 1. Assessment results for identified and undiscovered copper worldwide, by region.

[ $\mathrm{km}^{2}$, square kilometers; Mt, million metric tons; "90" indicates a 90-percent chance of at least the amount shown, with other percentiles similarly defined. Columns may not add to total because of rounding. Gray shading indicates no quantitative assessment]

\begin{tabular}{|c|c|c|c|c|c|c|c|}
\hline \multirow{2}{*}{ Region } & \multirow{2}{*}{ Deposit type } & \multirow{2}{*}{$\begin{array}{c}\text { Tract } \\
\text { extent } \\
\left(\mathbf{k m}^{2}\right)\end{array}$} & \multicolumn{4}{|c|}{ Undiscovered resources (Mt) } & \multirow{2}{*}{$\begin{array}{l}\text { Identified } \\
\text { resources } \\
\text { (Mt) }\end{array}$} \\
\hline & & & 90 & 50 & 10 & Mean & \\
\hline \multirow[t]{2}{*}{ South America } & Porphyry & $1,200,000$ & 500 & 730 & 1,000 & 750 & 810 \\
\hline & Sediment-hosted & 99,000 & & & & & 0.51 \\
\hline $\begin{array}{l}\text { Central America and } \\
\text { the Caribbean }\end{array}$ & Porphyry & 540,000 & 78 & 150 & 280 & 170 & 42 \\
\hline \multirow[t]{2}{*}{ North America } & Porphyry & $3,200,000$ & 250 & 370 & 540 & 400 & 470 \\
\hline & Sediment-hosted & 450,000 & 15 & 48 & 110 & 57 & 18 \\
\hline Northeast Asia & Porphyry & $2,300,000$ & 76 & 220 & 500 & 260 & 8.8 \\
\hline \multirow[t]{2}{*}{ North Central Asia } & Porphyry & $3,200,000$ & 210 & 360 & 590 & 440 & 130 \\
\hline & Sediment-hosted & 180,000 & 22 & 49 & 90 & 53 & 48 \\
\hline \multirow{2}{*}{$\begin{array}{l}\text { South Central Asia } \\
\text { and Indochina }\end{array}$} & Porphyry & $3,800,000$ & 280 & 490 & 770 & 510 & 63 \\
\hline & Sediment-hosted & 29,000 & & & & & 4.5 \\
\hline $\begin{array}{l}\text { Southeast Asia } \\
\text { Archipelagos }\end{array}$ & Porphyry & 850,000 & 180 & 290 & 430 & 300 & 130 \\
\hline Australia & Porphyry & 580,000 & 1.9 & 14 & 54 & 21 & 15 \\
\hline \multirow{2}{*}{$\begin{array}{l}\text { Eastern Europe and } \\
\text { Southwestern Asia }\end{array}$} & Porphyry & $1,200,000$ & 130 & 220 & 370 & 240 & 110 \\
\hline & Sediment-hosted & 4,800 & 0.052 & 4.8 & 36 & 13 & 6.4 \\
\hline \multirow[t]{2}{*}{ Western Europe } & Porphyry & 73,000 & & & & & 1.6 \\
\hline & Sediment-hosted & 190,000 & 38 & 110 & 230 & 120 & 77 \\
\hline $\begin{array}{l}\text { Africa and the } \\
\text { Middle East }\end{array}$ & Sediment-hosted & 200,000 & 81 & 150 & 260 & 160 & 160 \\
\hline Total copper & & & & & & 3,500 & 2,100 \\
\hline
\end{tabular}




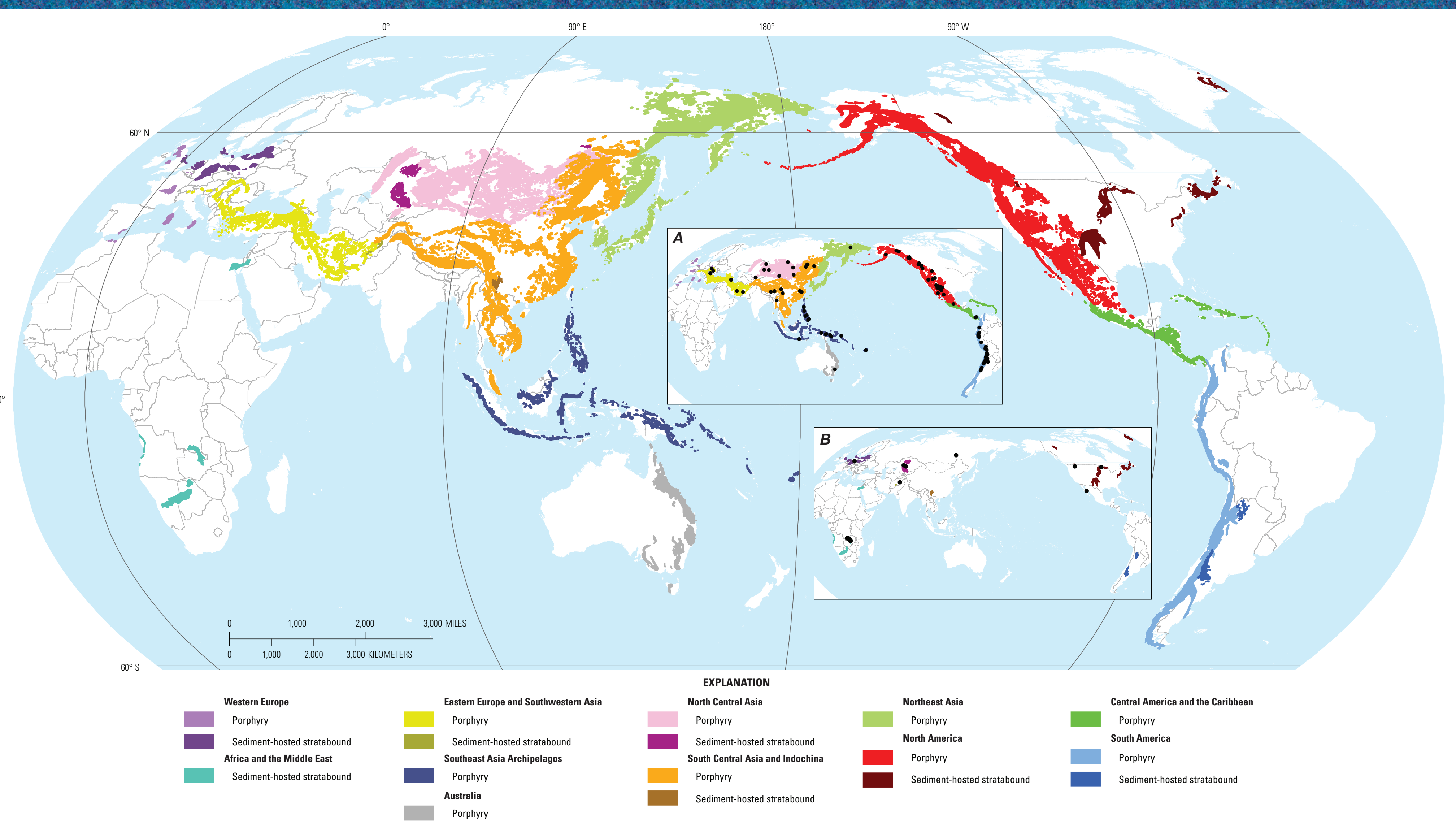

Figure 1. Locations of tracts assessed for this study, grouped by region and deposit type. Inset maps show identified deposits containing more than 2 million metric tons copper (black dots); $A$, porphyry copper; $B$, sediment-hosted stratabound copper. 
This study considered potential for exposed and concealed deposits within 1 kilometer $(\mathrm{km})$ of the surface for porphyry deposits and up to $2.5 \mathrm{~km}$ of the surface for sediment-hosted stratabound deposits. For porphyry deposits, 175 tracts were delineated; 114 tracts contain 1 or more identified deposits (fig. 1). Fifty tracts were delineated for sedimenthosted stratabound copper deposits; 27 contain 1 or more identified deposits.

Results of the assessment are provided by deposit type for 11 regions (table 1). The mean total undiscovered resource for porphyry deposits is $3,100 \mathrm{Mt}$, and the mean total undiscovered resource for sediment-hosted deposits is $400 \mathrm{Mt}$, for a global total of 3,500 Mt of copper. The ranges of resource estimates (between the 90th and 10th percentiles) reflect the geologic uncertainty in the assessment process. Approximately 50 percent of the global total occurs in South America, South Central Asia and Indochina, and North America combined.

South America has the largest identified and undiscovered copper resources (about 20 percent of the total undiscovered amount). The world's largest porphyry deposits are mined in this region.

Central America and the Caribbean host two undeveloped giant $(>2 \mathrm{Mt}$ copper) porphyry copper deposits in Panama. Most of the undiscovered resources are in a belt that extends from Panama to southwestern Mexico.

North America hosts highly mineralized porphyry copper tracts that include supergiant ( $>25 \mathrm{Mt}$ copper) porphyry deposits in northern Mexico, the western United States, and Alaska, as well as giant deposits in western Canada. The estimated undiscovered porphyry copper resources are approximately equal to the identified resources. In the United States, undiscovered sediment-hosted stratabound copper deposits in Michigan, Montana, and Texas are estimated to contain about three times as much copper as has been identified. Two giant deposits are known, in Michigan and Montana.

Northeast Asia is relatively underexplored, with modest identified porphyry copper resources and only one identified giant porphyry copper deposit. However, the mean undiscovered resources are estimated to be quite large. This region has the largest ratio of undiscovered to identified resources in the study.

North Central Asia has 35 porphyry copper deposits, including a supergiant deposit in Mongolia and a giant deposit in Kazakhstan. The tract area is estimated to contain about three times the amount of identified porphyry copper resource. This region also hosts three giant sediment-hosted stratabound copper deposits, in Kazakhstan and Russia. The USGS estimates that as much sedimenthosted stratabound copper as has already been discovered may be present.

South Central Asia and Indochina are less thoroughly explored than many other parts of the world; however, four giant porphyry copper deposits have been identified to date in the Tibetan Plateau. Undiscovered porphyry copper deposits may contain eight times the identified amount of copper.

\section{Southeast Asia Archipelagos} host world-class, gold-rich porphyry copper deposits such as a supergiant in Indonesia and about 16 giant deposits in Indonesia, Papua New Guinea, and the Philippines. Although parts of the region are well explored, undiscovered porphyry resources are likely to exceed identified resources.

Eastern Australia has one giant porphyry copper deposit and several small porphyry deposits. Modest undiscovered resources are expected under cover.

Eastern Europe and Southwestern Asia have been mined for copper since ancient times, and giant porphyry copper deposits have recently been identified.

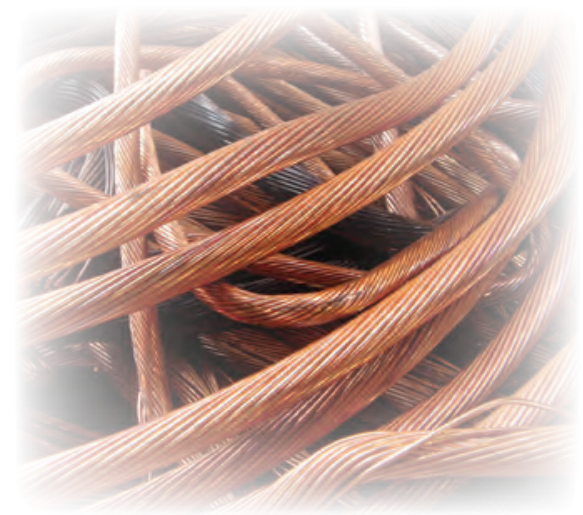

Undiscovered copper is predicted to be about twice the identified resources, both for porphyry deposits along a belt from Romania through Turkey and Iran and for sediment-hosted stratabound deposits in Afghanistan.

Western Europe has the largest sediment-hosted stratabound copper deposit in the world, in Poland. Undiscovered sediment-hosted stratabound copper resources in southwestern Poland are estimated to exceed identified resources by about 30 percent.

Africa and the Middle East have the world's largest accumulation of sediment-hosted stratabound copper deposits, with 19 giant deposits in the Central African Copperbelt in the Democratic Republic of Congo and Zambia. Significant undiscovered copper resources remain to be discovered.

\section{Reference Cited}

Edelstein, D.L., 2013, Copper, in Metals and minerals: U.S. Geological Survey Minerals Yearbook 2011, v. 1, p. 20.1-20.25, accessed January 24, 2014, at http://minerals.usgs.gov/ minerals/pubs/commodity/copper/ myb1-2011-coppe.pdf.

\section{For Further Information}

Supporting studies, including documentation of the assessment methodology and descriptions of individual tracts, are available on the USGS Mineral Resources Program Web site, http://minerals.usgs.gov/global/.

Information on production and consumption of copper is available from USGS at http://minerals.usgs.gov/minerals/pubs/commodity/copper/.

Contact: minerals@usgs.gov 